\title{
Effect of seed age and fertilisation on the growth and decorative quality of selected ornamental grasses
}

Anna Kapczyńska

\author{
Department of Ornamental Plants \\ University of Agriculture in Krakow \\ 29 Listopada 54, 31-425 Kraków, Poland
}

\begin{abstract}
Ornamental grasses have become a popular group of plants for use in landscaping. The aim of the present experiment was to assess the influence of seed age on the germination of ornamental grasses. In the glasshouse experiment, seeds of three grass genera, Melica, Pennisetum and Stipa, were tested. The seeds came from the Plant Breeding and Acclimatisation Institute in Bydgoszcz. They were harvested in 2005, 2006 and 2007 (so they were three years old, two years old, and one year old, respectively). In all the genera, the youngest seeds showed the highest germination, which varied between 61\% (Melica transsilvanica) and 74\% (Melica ciliata ssp. taurica). The germination process of the oldest seeds (three years old) proceeded at various rates, depending on the species, but the highest ability to germinate was observed in Pennisetum flaccidum (39\%) and Stipa tenuissima (42\%). After germination, Melica sp. and Stipa sp. plants were repotted and treated with Hydrocote (a slow-release fertiliser). The results obtained indicated that the fertilisation of the grasses significantly increased the height of the plants. Plants of Melica altissima 'Atropurpurea' also formed three times more inflorescences than the control plants. The application of the fertiliser had a positive effect on leaf colour (a more intense green) in all of the tested genera.
\end{abstract}

Key words: germination, Hydrocote, Melica, Pennisetum, Stipa

\section{INTRODUCTION}

Wild grasses have always been a part of our natural environment and now, thanks to their versatility, ornamental grasses have become increasingly popular in our gardens. The investigated species may all be recommended as a decorative component in landscaping, enriching the garden experience with movement and sound. In the literature, grasses are mostly treated as botanical objects that are a part of the Polish landscape (Frey 2007), but there are still not many academic publications that concern grasses as an element of garden landscaping. Poaceae is represented by a great diversity of species, thus the knowledge concerning the germination requirements of individual species may be economically important to nurseries. Grasses are propagated mainly by division and seeds. Generative propagation is used in the case of the species and varieties with stable genetic features and it is one of the cheapest and most efficient ways to obtain new plants. There are many external factors that influence the course of germination, e.g. temperature (Vleeshouvers et al. 1995). Gulzar and Khan's (2001) study demonstrates that Aeluropus 
lagopoides seeds germinate in $100 \%$ at $20-30^{\circ} \mathrm{C}$, but increases and decreases in the temperature regime inhibit the germination process. Moreover, the temperature is regarded as a principal factor in designing seed stores and understanding seed ecology (Roberts 1988). Seed age may play a primary role in the germination process (Khalid and Siddiqui 2002). The seed ageing process (physiological degradation) is treated as an internal feature of each individual plant and it mostly depends on the genes. Some seeds are naturally very short-lived (Salix sp.) (Maroder et al. 2000), while other seeds may easily retain viability for hundreds of years (Carex bigelowii) (McGraw et al. 1991). To create a germination model of an individual species, it is necessary to establish for how long the seeds remain capable of germination and if the rate of failure increases as the seeds age. This information may be of great importance in relation to seed storage.

Each grass species has its own unique form. Grasses are often grown on poor soils and some of them are extremely adaptable. Furthermore, it is possible to use perennial species of grass in biological recultivation of post-industrial waste areas (Majtkowski 2000) and the application of low-level fertilisation may help the plants to maintain their decorative function by revealing the full extent of their colour, shape, texture or size.

The objective of this study was to determine the effects of seed age on the germination process and of fertilisation on the growth and decorative qualities of some ornamental grasses.

\section{MATERIAL AND METHODS}

The experiment concerning the effect of seed age on germination was conducted in a greenhouse of the Faculty of Horticulture of the University of Agriculture in Krakow in 2008. The seeds of three ornamental grasses, Melica, Pennisetum and Stipa, were received from the Plant Breeding and Acclimatization Institute in Bydgoszcz. The seeds were harvested in 2005, 2006 and 2007 (so at the time of the experiment they were three, two and one year old, respectively). The individual species and the harvest year of seeds (seed age) are presented in Table 1. After harvest, the seeds were dry stored at $22^{\circ} \mathrm{C}$ and $30 \% \mathrm{RH}$. Before sowing, the weight (g) of 1000 seeds and their number per gram were determined separately for each species harvested in the different years. The seeds of Stipa capillata were stored at $2-5^{\circ} \mathrm{C}$ for three weeks before sowing as they needed to undergo stratification (Fulbright et al. 1983). On 22 April 2008, the seeds were sown
Table 1. The list of grasses used $(+)$ in the experiment

\begin{tabular}{lccc}
\hline & \multicolumn{3}{c}{ Seed age (harvest year) } \\
\cline { 2 - 4 } Species/cultivar & $\begin{array}{c}\text { 1-year- } \\
\text { old } \\
(2007)\end{array}$ & $\begin{array}{c}\text { 2-years- } \\
\text { old } \\
(2006)\end{array}$ & $\begin{array}{c}3 \text {-years- } \\
\text { old } \\
(2005)\end{array}$ \\
\hline M. altissima & & + & + \\
M. altissima 'Atropurpurea' & + & + & + \\
M. ciliata ssp. taurica & + & + & + \\
M. transsilvanica & + & + & + \\
P. flaccidum & + & + & + \\
P. glaucum & & + & \\
P. glaucum 'Candlestick' & & + & \\
P. setaceum & & + & + \\
S. capillata & & & + \\
S. tenuissima & & & + \\
\hline
\end{tabular}

singly in window boxes filled with a mixture of peat and sand at a 1:1 ratio. The ambient temperature during the germination period was about $20^{\circ} \mathrm{C}$. The emerging seedlings were initially counted every day, then with poorer germination every third day, and later every sixth day until the time when no more emergences were observed for 14 successive days. The appearance of the first leaf was used as the criterion for germination. The evaluated items were: the number of days from sowing to the beginning of germination (emergence), the length of the germination period and germination percentage. Each object was represented by 200 seeds, with 50 seeds in 4 replications.

To explore the effects of fertilisation on the growth and decorative quality of the grasses, plants (obtained from the germinated seeds) of Melica altissima 'Atropurpurea', Melica ciliata ssp. taurica, Melica transsilvanica, Stipa capillata and Stipa tenuissima were planted on 17 June 2008 , in $12 \mathrm{~cm}$ diameter pots filled with the AURA substrate. A chemical analysis of the substrate showed the following element contents $\left(\mathrm{mg} \mathrm{dm}^{-3}\right)$ : $\mathrm{N}\left(\mathrm{N}-\mathrm{NO}_{3}\right)-88, \mathrm{P}-80, \mathrm{~K}-290, \mathrm{Ca}-1310, \mathrm{Mg}-$ $118, \mathrm{Cl}-41, \mathrm{pH}=6.46$. The substrate was supplied with a Hydrocote slow-release fertiliser $\left(3 \mathrm{~g} \mathrm{dm}^{-3}\right)$. The control plants were planted in the substrate without fertiliser. The experiment was carried out in four replications, each treatment consisting of 80 plants. The grasses were evaluated from the $5^{\text {th }}$ to $10^{\text {th }}$ of September. The choice of evaluated traits depended on the plant developmental stage and the genus. The plant height including and excluding inflorescence, the inflorescence length, the number of culms and inflorescences per plant were determined for the genus Melica. The plant 
height excluding inflorescence and the number of stems were measured for the genus Stipa. The colour of leaves was assessed for all accessions by using the RHS Colour Chart.

The results of the germination and the fertilisation experiments were evaluated statistically using analysis of variance for a one-factor experiment, with the Duncan test applied at the significance level of $\mathrm{p}=0.05$.

\section{RESULTS AND DISCUSSION}

It is considered that seed weight is a comparatively stable characteristic in plants, but sometimes it can vary, e.g. the largest seeds can be produced by the plant first and then, progressively, smaller seeds ripen as the plant ages (Cavers and Steele 1984). The seeds used in this experiment were collected over three years from a group of plants growing in the same habitat. The differences in seed weight between the species were noticeable. According to the data presented in Table 2, the plants of Melica transsilvanica produced the heaviest seeds in this genus, while the seeds of $M$. ciliata ssp. taurica were 12 times lighter. In the case of the genus Pennisetum, the seeds of $P$. glaucum 'Candlestick' were heavier than seeds of $P$. glaucum, and $P$. flaccidum.

The data concerning the changes in germination percentage (Tab. 3) showed that the investigated seeds lost their viability with age. The germination of the three-year-old seeds of $M$. altissima 'Atropurpurea' and M. ciliata ssp. taurica decreased and the percentage of emerging seedlings was lower by 67 percentage points than the emergence rate of the one-year-old seeds. A similar situation was observed in M. transsilvanica and P. flaccidum the germination of the oldest seeds was respectively lower by 34 and 28 percentage points than the capacity of the youngest seeds. None of the threeyear-old seeds of $M$. altissima sprouted. The results showed that none of the species had a $100 \%$ germination rate. The effect of seed age on the germination process was also stressed by Ouled

Table 2. The effect of seed age on the seed characteristic

\begin{tabular}{lcccccc}
\hline \multirow{2}{*}{ Species/cultivar } & \multicolumn{3}{c}{ 1000 seed weight (g) } & \multicolumn{3}{c}{ Number of seeds per gram } \\
\cline { 2 - 7 } & 1-year-old & 2-year-old & 3-year-old & 1-year-old & 2-year-old & 3-year-old \\
\hline M. altissima & - & 1.31 & 1.63 & - & 763.4 & 613.5 \\
M. altissima 'Atropurpurea' & 1.32 & 1.35 & 1.68 & 757.6 & 740.7 & 597.0 \\
M. ciliata ssp. taurica & 0.36 & 0.36 & 0.41 & 2785.5 & 2754.8 & 2421.3 \\
M. transsilvanica & 4.46 & 4.20 & 5.60 & 224.2 & 238.1 & 178.6 \\
P. flaccidum & 9.90 & 8.76 & 9.10 & 101.0 & 114.2 & 109.9 \\
P. glaucum & - & 0.37 & - & - & 2688.2 & - \\
P. glaucum 'Candlestick' & - & 46.62 & - & - & 21.5 & - \\
P. setaceum & - & 9.80 & 9.55 & - & 102.0 & 104.7 \\
S. capillata & - & - & 52.60 & - & - & 19.0 \\
S. tenuissima & - & - & 3.22 & - & - & 310.6 \\
\hline
\end{tabular}

Table 3. Effect of seed age on their germination (\%)

\begin{tabular}{lccc}
\hline Species/cultivar & 1-year-old & 2-year-old & 3-year-old \\
\hline M. altissima & - & $48.5 \mathrm{~b}^{*}$ & $0.0 \mathrm{a}$ \\
M. altissima 'Atropurpurea' & $70.0 \mathrm{c}$ & $32.5 \mathrm{~b}$ & $3.5 \mathrm{a}$ \\
M. ciliata ssp. taurica & $74.5 \mathrm{c}$ & $42.5 \mathrm{~b}$ & $7.5 \mathrm{a}$ \\
M. transsilvanica & $61.0 \mathrm{c}$ & $42.5 \mathrm{~b}$ & $27.0 \mathrm{a}$ \\
P. flaccidum & $67.5 \mathrm{~b}$ & $41.6 \mathrm{a}$ & $39.1 \mathrm{a}$ \\
P. glaucum & - & 17.5 & - \\
P. glaucum 'Candlestick' & - & 36.0 & - \\
P. setaceum & - & $10.8 \mathrm{~b}$ & $3.5 \mathrm{a}$ \\
S. capillata & - & - & 17.0 \\
S. tenuissima & - & - & 42.5 \\
\hline
\end{tabular}

*Values in rows marked with the same letters do not differ significantly at $\mathrm{p}=0.05$ 


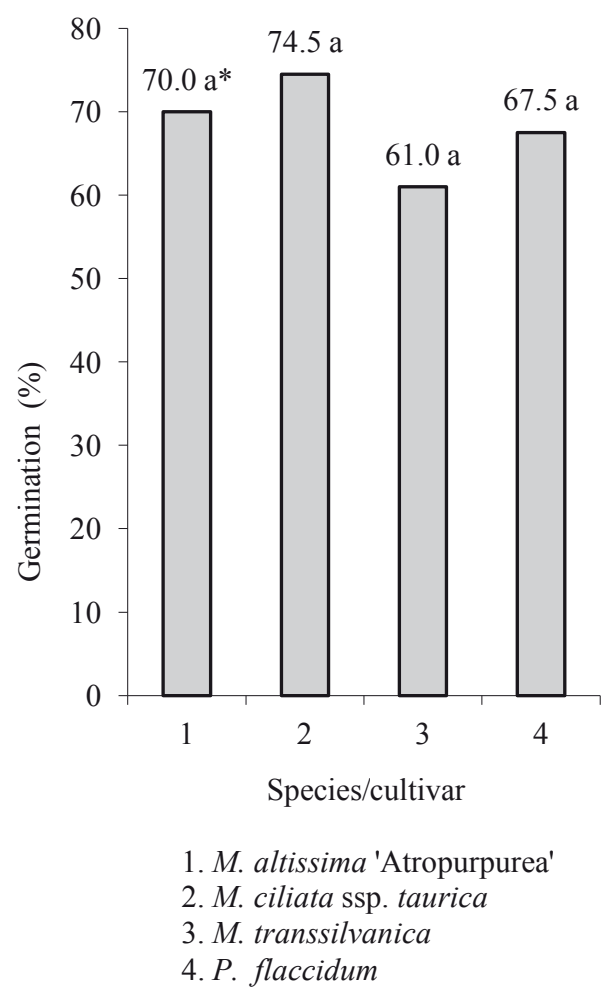

Figure 1. Germination percentage of one year old seeds

*Values marked with the same letters do not differ significantly at $\mathrm{p}=0.05$

Belgacem et al. (2006), who claim that younger Stipa lagascae seeds have higher emergence rates than older seeds. Germination is not only affected by seed age but also by the weather. Goodwin et al. (1995) came to the conclusion that seeds produced in a very dry year had a lower capacity for germination and shorter longevity. The storage conditions also affect the seed longevity. Storage temperature and $\mathrm{RH}$ are regarded as the two most important factors influencing the subsequent process of germination (Alhabdan et al. 2011). The group of one-year-old seeds did not significantly differ in their germination - the studied species germinated at a rate of $61-75 \%$ (Fig. 1). But the germination behaviour of equally aged seeds may significantly vary between species. As regards the two-year-old seeds, it was found that the highest germination (nearly 50\%) was achieved by $M$. altissima seeds, while the poorest germination was recorded in the case of $P$. glaucum and $P$. setaceum seeds (Fig. 2). Compared with all the seeds harvested in 2005, the germination of the three-year-old seeds of S. tenuissima and $P$. flacidum was the highest and amounted to 42 and 39\%, respectively (Fig. 3). It is worth emphasising that the germination characteristic may be different even for grasses belonging to the same genus, and so the capacity of $M$. transsilvanica seeds is as much as nine times higher than that of M. altissima 'Atropurpurea'; similarly, the capacity of $S$. tenuissima seeds is nearly three times higher than that of $S$. capillta seeds. Gasque and GarcíaFayos (2003) claim that in the genus Stipa there is a significant variation in seed germination among individuals, populations and years of harvest.

The results of the experiment concerning the number of days from sowing to the beginning of

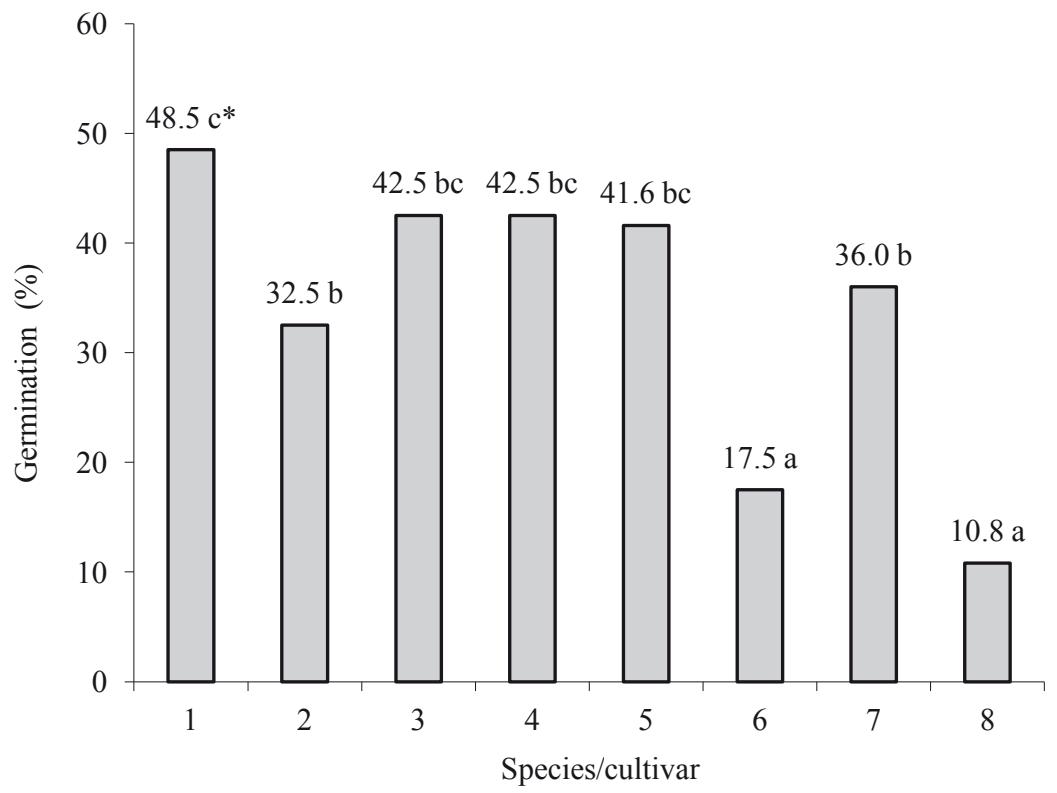

Figure 2. Germination percentage of two year old seeds

*Explanations: see Figure 1 


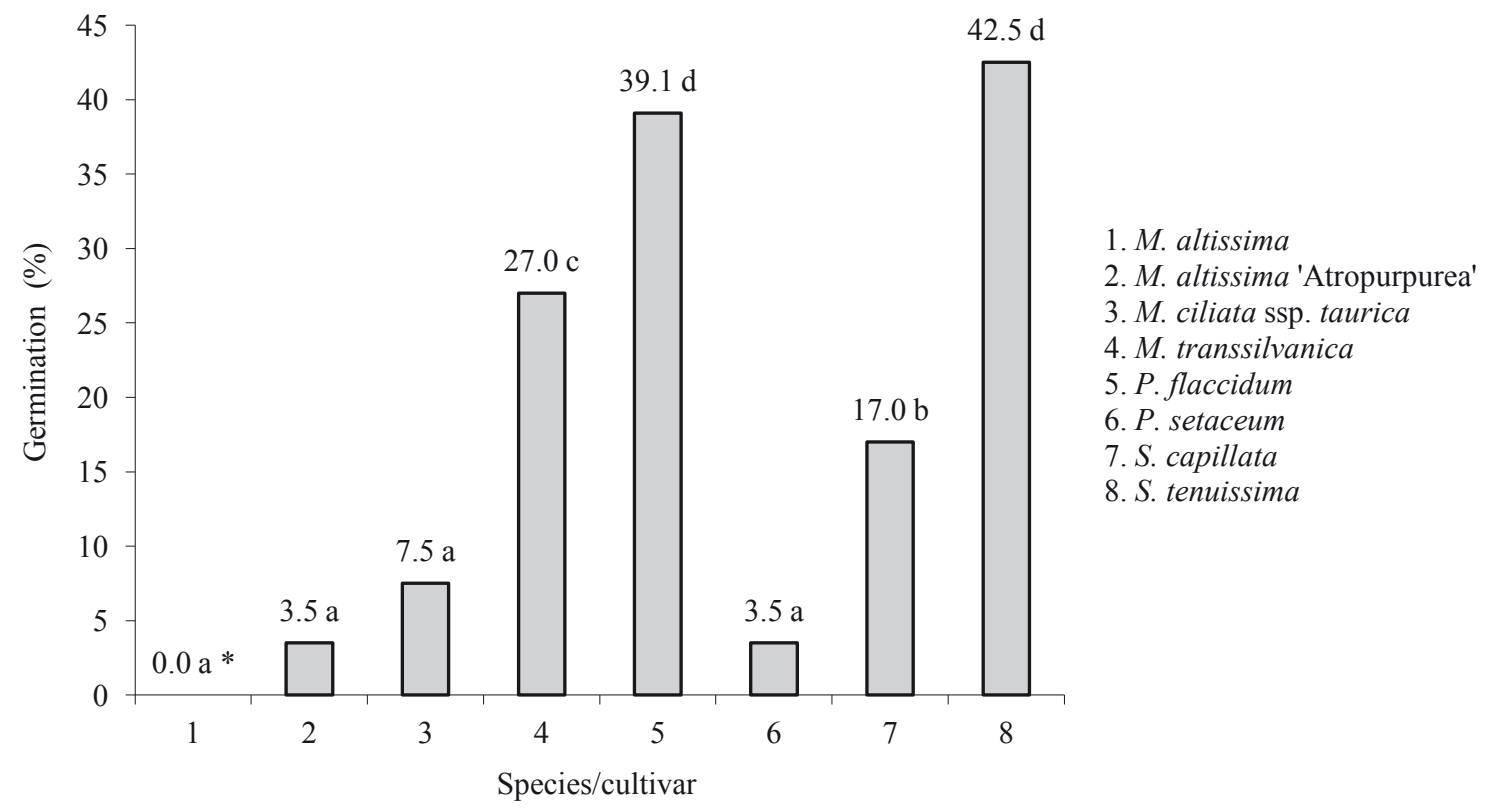

Figure 3. Germination percentage of three year old seeds

*Explanations: see Figure 1

germination show that this value varied between 6 and 14 days depending on the species and harvest year (Tab. 4). No significant effect of the seed age on the time of emergence was observed in M. altissima 'Atropurpurea', P. flaccidum and P. setaceaum. The three-year-old seeds of $M$. ciliata ssp. taurica needed more days to sprout than the two-year-old and oneyear-old seeds. A similar tendency can be discerned for the germination of M. transsilvanica - the threeand two-year-old seeds germinated 3-4 days later in comparison with the youngest ones. It corresponds to the findings of Rice and Dyer (2001), who stated that four-year-old seeds of Bromus tectorum from a meadow-steppe population exhibited delays in germination that reduced the plant's growth in a competitive environment. In addition, Colbach and Dürr (2003) claimed that Alopecurus myosuroides seeds germinated best and fastest when they were collected in spring crops rather than winter crops.

In most of the grass species the seed age did not affect the length of the germination period (Tab. 5). Only the one-year-old seeds of P. flaccidum completed the germination process about six days later compared with the two- and three-year-old seeds.

Little information is available on the nursery production of ornamental grasses and the fertilisation applied to them. Some growers claim these plants require relatively low levels of soil fertility, and the application of a slow-release

Table 4. Effect of seed age on the number of days from sowing to emergence

\begin{tabular}{lccc}
\hline Species/cultivar & 1-year-old & 2-year-old & 3-year-old \\
\hline M. altissima & - & $8.0 \mathrm{~b}$ & $0.0 \mathrm{a}$ \\
M. altissima 'Atropurpurea' & $11.0 \mathrm{a}$ & $9.5 \mathrm{a}$ & $9.0 \mathrm{a}$ \\
M. ciliata ssp. taurica & $7.2 \mathrm{a}$ & $10.2 \mathrm{a}$ & $14.2 \mathrm{~b}$ \\
M. transsilvanica & $9.0 \mathrm{a}$ & $11.7 \mathrm{~b}$ & $13.2 \mathrm{~b}$ \\
P. flaccidum & $6.5 \mathrm{a}$ & $7.5 \mathrm{a}$ & $6.7 \mathrm{a}$ \\
P. glaucum & - & 7.2 & - \\
P. glaucum 'Candlestick' & - & 7.0 & - \\
P. setaceum & - & $6.5 \mathrm{a}$ & $7.5 \mathrm{a}$ \\
S. capillata & - & - & 11.5 \\
S. tenuissima & - & - & 10.7 \\
\hline
\end{tabular}

*Explanations: see Table 3 
Table 5. Effect of seed age on the length of the germination period (days)

\begin{tabular}{lccc}
\hline Species/cultivar & 1-year-old & 2-year-old & 3-year-old \\
\hline M. altissima & - & $20.0 \mathrm{~b}^{*}$ & $0.0 \mathrm{a}$ \\
M. altissima 'Atropurpurea' & $19.7 \mathrm{a}$ & $19.5 \mathrm{a}$ & $20.0 \mathrm{a}$ \\
M. ciliata ssp. taurica & $18.7 \mathrm{a}$ & $19.7 \mathrm{a}$ & $19.2 \mathrm{a}$ \\
M. transsilvanica & $19.5 \mathrm{a}$ & $21.2 \mathrm{a}$ & $21.0 \mathrm{a}$ \\
P. flaccidum & $24.2 \mathrm{~b}$ & $17.7 \mathrm{a}$ & $18.5 \mathrm{a}$ \\
P. glaucum & - & 15.7 & - \\
P. glaucum 'Candlestick' & - & 16.0 & - \\
P. setaceum & - & $10.2 \mathrm{a}$ & $7.5 \mathrm{a}$ \\
S. capillata & - & - & 24.5 \\
S. tenuissima & - & - & 20.5 \\
\hline
\end{tabular}

*Explanations: see Table 3

fertiliser or compost before the active growth period may be adequate enough for them. Overfertilizing can lead to falling-over and rank growth. The results included in Table 6 indicate that the application of Hydrocote had a significant effect on the number of inflorescences produced by all the flowered grasses. The M. altissima 'Atropurpurea' plants treated with the fertiliser had nearly three times more inflorescences in comparison with the control plants. At the same time, it was found that the spikes of $M$. altissima 'Atropurpurea' and $M$. ciliata ssp. taurica were respectively 8 and nearly $2 \mathrm{~cm}$ longer than those of the plants cultivated in the unfertilised soil. The growth parameters of the control plants, namely the number of culms and plant height, were lower in comparison with those of the fertilised plants (Tab. 7). The fertilisation treatment had no effect on the number of culms only in the case of S. tenuissima, but the plants of this species formed more than 200 blades during one season. This observation agrees with the results reported by Lanyasunya et al. (2007). They claim that fertiliser application has a significant effect on the height of Sorghum almum, and this feature is strongly correlated with the concentration of essential nutrients in the plant's tissues.

Leaf colour was determined using the RHS colour chart. It is a visual indicator of nitrogen deficiency in plants and serves as a practical diagnostic tool that is easy to use by nurseries. The results included in Table 8 indicate that the foliage of all the fertilised grasses had more green

Table 6. Effect of fertilisation on select inflorescence characteristicists

\begin{tabular}{llccc}
\hline & & $\begin{array}{c}\text { M. altissima } \\
\text { "Atropurpurea' }\end{array}$ & $\begin{array}{c}\text { M. ciliata } \\
\text { ssp. taurica }\end{array}$ & $\begin{array}{c}\text { M. } \\
\text { transsilvanica }\end{array}$ \\
\hline Number of & control & $2.0 \mathrm{a}^{*}$ & $2.0 \mathrm{a}$ & $2.7 \mathrm{a}$ \\
inflorescences per plant & fertilised plants & $5.4 \mathrm{~b}$ & $2.6 \mathrm{~b}$ & $3.4 \mathrm{~b}$ \\
Inflorescence length & control & $5.7 \mathrm{a}$ & $8.1 \mathrm{a}$ & $7.4 \mathrm{a}$ \\
$(\mathrm{cm})$ & fertilised plants & $14.1 \mathrm{~b}$ & $9.8 \mathrm{~b}$ & $7.4 \mathrm{a}$ \\
Plant height including & control & $33.0 \mathrm{a}$ & $35.9 \mathrm{a}$ & $35.9 \mathrm{a}$ \\
inflorescence $(\mathrm{cm})$ & fertilised plants & $62.0 \mathrm{~b}$ & $43.3 \mathrm{~b}$ & $40.4 \mathrm{~b}$ \\
\hline
\end{tabular}

*Values in columns marked with the same letters do not differ significantly at $p=0.05$

Table 7. Effect of fertilisation on growth parameters

\begin{tabular}{llccccc}
\hline & & $\begin{array}{c}\text { M. altissima } \\
\text { 'Atropurpurea' }\end{array}$ & $\begin{array}{c}\text { M. ciliata } \\
\text { ssp. taurica }\end{array}$ & $\begin{array}{c}\text { M. } \\
\text { transsilvanica }\end{array}$ & $\begin{array}{c}\text { S. } \\
\text { capillata }\end{array}$ & $\begin{array}{c}\text { S. } \\
\text { tenuissima }\end{array}$ \\
\hline Number of culms per & control & $15.9 \mathrm{a} *$ & $11.6 \mathrm{a}$ & $10.5 \mathrm{a}$ & $59.5 \mathrm{a}$ & $208.4 \mathrm{a}$ \\
plant & fertilised plants & $20.4 \mathrm{~b}$ & $19.7 \mathrm{~b}$ & $13.7 \mathrm{~b}$ & $89.2 \mathrm{~b}$ & $211.2 \mathrm{a}$ \\
Plant height excluding & control & $27.3 \mathrm{a}$ & $27.8 \mathrm{a}$ & $28.4 \mathrm{a}$ & $28.6 \mathrm{a}$ & $41.0 \mathrm{a}$ \\
inflorescence $(\mathrm{cm})$ & fertilised plants & $48.8 \mathrm{~b}$ & $33.4 \mathrm{~b}$ & $33.3 \mathrm{~b}$ & $31.5 \mathrm{~b}$ & $57.2 \mathrm{~b}$ \\
\hline
\end{tabular}

*Explanations: see Table 6 
Table 8. Colour of leaves according to RHS Colour Chart

\begin{tabular}{lccccc}
\hline & M. altissima & M. ciliata & M. & S. & S. \\
& 'Atropurpurea & ssp. taurica & transsilvanica & capillata & tenuissima \\
\hline \multirow{2}{*}{ Control } & Yellow - Green & Yellow - Green & Green & Green & Yellow - Green \\
& $144 \mathrm{C}$ & $144 \mathrm{~A}$ & $138 \mathrm{~B}$ & $138 \mathrm{~B}$ & $144 \mathrm{~A}$ \\
\multirow{2}{*}{ Fertilised plants } & Green & Green & Green & Green & Green \\
& $137 \mathrm{C}$ & $137 \mathrm{~A}$ & $138 \mathrm{~A}$ & $137 \mathrm{C}$ & $143 \mathrm{~A}$ \\
\hline
\end{tabular}

coloration compared to the yellowish-green leaves of the control plants. Using a leaf colour chart (e.g. LCC) is a common practice among rice and maize (Poaceae) farmers (Islam et al. 2007). Such a chart makes it possible to apply adequate amounts of nitrogen and avoid excessive fertiliser applications (thus helping to minimize fertiliser-related pollution of ground water). Fertilisation treatments of ornamental grasses may be especially important in urban areas, where the soils are low in organic matter, in the sense that fertiliser applications may improve the grasses' growth and leaf colour. It should be pointed out that among ornamental grasses, there are species that change the size of the clump relatively slowly throughout the years of cultivation (Calamagrostis acutiflora), while other species (Phalaris arundinaceae or Muehlenbergia mexicana) are very expansive (Pudelska 2008). Grasses with high growth dynamics may be very invasive, and for them a typical garden soil may be adequate enough for proper plant development and flowering.

\section{CONCLUSIONS}

1. The germination of the investigated species did not exceed $75 \%$.

2. The time from sowing to emergence varied between six and 14 days depending on the species and seed age.

3. The seed age of the majority of the grasses studied did not exert an influence on the length of the germination period.

4. A significant effect of fertilisation on the yield of inflorescences and the height of plants was found.

5. The application of a slow-release fertiliser had a positive effect on leaf colour in all the ornamental grasses investigated.

\section{REFERENCES}

Alhabdan M.A., Alsadon A.A., Khalil S.O., WahbAllah M.A., El Nagar M., Ibrahim A.A., 2011. Influence of storage conditions on seed quality and longevity of four vegetable crops. AmericanEurasian J. Agric. \& Environ. Sci. 11(3): 353-359.

Cavers P.B., Steele M.G., 1984. Patterns of change in seed weight over time on individual plants. Am. Nat. 124: 324-335.

Colbach N., DürR C., 2003. Effects of seed production and storage condition on blackgrass (Alopecurus myosuroides) germination and shoot elongation. Weed Sci. 51: 708-717.

FrEY L., 2007. Księga polskich traw. Instytut Botaniki im. W. Szafera, PAN, Kraków.

Fulbright T.E., Redente E.F., Wilson A.M., 1983. Germination requirements of green needle grass (Stipa viridula Trin.). J. Range Manage 36(3): 390394.

Gasque M., García-Fayos P., 2003. Seed dormancy and longevity in Stipa tenacissima L. (Poaceae). Vegetatio 168(2): 279-290.

Goodwin J.R., Doescher P.S., Eddleman L.E., 1995. After-ripening in Festuca idahoensis seeds: adaptive dormancy and implications for restoration. Rest. Ecol. 3(2): 137-142.

Gulzar S., KHAN M.A., 2001. Seed germination of a halophytic grass Aeluropus lagopoides. Ann. Bot. 87: 319-324.

Islam Z., Bagchi B., Hossain M., 2007. Adoption of leaf color chart for nitrogen use efficiency in rice: Impact assessment of a farmer-participatory experiment in West Bengal, India. Field Crop. Res. 103(1): 70-75.

Khalid S., Siddiqui S.U., 2002. Wild oats (Avena fatua L.) seed viability and dormancy as influenced by seed age and size; and the variable germination temperature regimes. Pakistan J. Agric. Res. 17(4): 335-341.

Lanyasunya T.P., Wang Rong H., Mukisira E.A., Kibitok N.K., 2007. Effect of manure or fertilizer application on height of Sorghum almum harvested at different maturity stages. Agric. J. 2: 82-86.

Maroder H.L., Prego I.A., Facciuto G.R., Maldonado S.B., 2000. Storage behavior of Salix alba and Salix matsudana seeds. Ann. Bot. 86: 1017-1021.

MajtKowski W., 2000. North American grass species in reclamation of coal-mining areas in Poland. Proc. XVIII Int. Grassland Congress, Winnipeg \& Saskatoon, Canada, 8-19 June 1997; vol. 2(16): 37-38.

McGraw J.B., Vavrek M.C., Bennington C.C., 1991. Ecological genetic variation in seed banks I. Establishment of a time transect. J. Ecol. 79: 617625. 
Ouled Belgacem A., Neffati M., Papanastasis V.P., Chaieb M., 2006. Effects of seed age and seeding depth on growth of Stipa lagascae R. \& Sch. seedlings. J. Arid Env. 65(4): 682-687.

Pudelska K., 2008. Evaluation of growing and flowering of five species of ornamental grasses in the region of Lublin. Acta Agrobot. 61(1): 173-178.

Rice K.J., Dyer A.R., 2001. Seed aging, delayed germination and reduced competitive ability in Bromus tectorum. Plant Ecol. 155: 237-243.

RoBerts E.H., 1988. Temperature and seed germination. Symp. Soc. Exp. Biol. 42: 109-132.

Vleeshouvers L.M., Bouwmeester H.J., Karssen C.M., 1995. Redefining seed dormancy: an attempt to integrate physiology and ecology. J. Ecol. 83: 10311037.

\section{WPEYW WIEKU NASION ORAZ NAWOŻENIA NA ROZWÓJ I WALORY DEKORACYJNE WYBRANYCH GATUNKÓW TRAW OZDOBNYCH}

Streszczenie: Trawy ozdobne to grupa roślin coraz częściej stosowana w kompozycjach ogrodowych. W przeprowadzonych badaniach analizowano wpływ wieku nasion na proces kiełkowania wybranych gatunków traw ozdobnych. Po uzyskaniu roślin z siewu oceniano wpływ nawożenia na wybrane cechy. Doświadczenia przeprowadzono w 2008 roku w szklarniach
Wydziału Ogrodniczego UR w Krakowie. Materiałem badawczym były nasiona traw otrzymane z IHiAR w Bydgoszczy, które zebrano w: 2007, 2006 i 2005 roku (nasiona 1-roczne, 2-letnie i 3-letnie). Badano gatunki z rodzaju Melica, Pennisetum i Stipa. Najwyższą zdolnością kiełkowania charakteryzowały się nasiona 1-roczne. Zdolność kiełkowania tych nasion u wszystkich badanych gatunków była zbliżona i wynosiła od 61 (Melica transsilvanica) do 74\% (Melica ciliata ssp. taurica). Nasiona najstarsze (zbiór 2005 rok) poszczególnych gatunków wykazywały różną zdolność kiełkowania, a najwyższą wartość badanej cechy wykazały nasiona piórówki - Pennisetum flaccidum (39\%) oraz ostnicy - Stipa tenuissima (42\%). Siewki pięciu gatunków traw (z rodzajów: Melica i Stipa) po skiełkowaniu przesadzono do podłoża wzbogaconego nawozem Hydrocote. Uzyskane rośliny badanych gatunków były wyższe w porównaniu do obiektów kontrolnych. Rośliny perłówki wyniosłej (Melica altissima 'Atropurpurea') potraktowane nawozem wytworzyły prawie trzykrotnie więcej kwiatostanów w stosunku do roślin nie zasilanych. Wszystkie nawożone gatunki wytworzyły liście o intensywniejszej barwie od roślin kontrolnych.

Received July 7, 2011; accepted April 18, 2012 